\title{
Ploidy level of the representatives of Chenopodiaceae based on genome size and chromosome numbers
}

\author{
M. N. Lomonosova ${ }^{1 *}$, T. V. An'kova ${ }^{1}$, M. S. Voronkova ${ }^{1}$, E. A. Korolyuk ${ }^{1}$, E. V. Banaev ${ }^{1}$, M. V. Skaptsov² \\ ${ }^{1}$ Federal State Institution of Science Central Siberian Botanical Garden of Siberian Branch of RAS, Zolotodolinskaya str., \\ 101, Novosibirsk, 630090, Russian Federation \\ ${ }^{2}$ South-Siberian Botanical Garden, Altai State University, Lenina Pr., 61, Barnaul, 656049, Russian Federation. \\ E-mail:mr.skaptsov@mail.ru \\ *Corresponding author.E-mail: mlomonosova@mail.ru
}

Keywords: cytotype, DNA content in nuclei, flow cytometry, karyology, polyploidy.

Summary. The article presents the results of measuring the genome size (DNA content in nuclei) by flow cytometry and determining the ploidy level for 30 species of the Chenopodiaceae family in 50 natural populations from Russia, Armenia, Belarus, Kazakhstan, Tajikistan and South Korea. Genome size of 12 species was determined for the first time; they are: Atriplex patens, A. pedunculata, A. sibirica, A. verrucifera, Axyris amaranthoides, Camphorosma songorica, Ceratocarpus arenarius, Chenopodium vachellii, Corispermum declinatum, Oxybasis gubanovii, Salsola collina, Spirobassia hirsuta. Along with flow cytometric analysis, ploidy level of 13 species (Atriplex patens, A. prostrata, Bassia prostrata, Chenopodium album, C. betaceum, C. frutescens, C. karoi, C. luteorubrum, C. novopokrovskianum, C. strictum s. 1., C. vachellii, Krascheninnikovia ceratoides, and Oxybasis gubanovii) from 23 populations was determined by direct chromosome counting. Genome size of 11 species was studied in two or more populations. It was shown that differences in the genome size of samples in populations from different part of the area did not exceed $5 \%$ in diploids (Atriplex sagittata, A. sibirica) and tetraploids (Atriplex patens, Chenopodium album, C. betaceum, C. novopokrovskianum, C. strictum and Krascheninnikovia ceratoides). Two cytotypes were identified in Bassia prostrata: diploid in the Republic of Altai and tetraploid in Novosibirsk Region. A tetraploid cytotype of Chenopodium sosnovskyi was revealed in Armenia. It was shown that the genome size can be a reliable criterion to determine the ploidy level in related taxa of the Chenopodiaceae.

\section{Уровень плоидности представителей семейства Chenopodiaceae, выявленный по размеру генома и числам хромосом}

М. Н. Ломоносова ${ }^{1}$, Т. В. Анькова ${ }^{1}$, М. С. Воронкова ${ }^{1}$, Е. А. Королюк ${ }^{1}$, Е. В. Банаев ${ }^{1}$, М. В. Скапцов ${ }^{2}$

\footnotetext{
${ }^{1}$ Учреждение Российской академии наук Центральный сибирский ботанический сад Сибирского отделения РАН, ул. Золотодолинская, 101, г. Новосибирск, 630090, Россия

${ }^{2}$ Южно-Сибирский ботанический сад, Алтайский государственный университет, пр. Ленина, 61, г. Барнаул, 656049, Россия
}

Ключевые слова: кариология, полиплоидия, проточная цитометрия, содержание ДНК в ядрах, цитотип.

Аннотация. В статье представлены результаты измерения размера генома (содержания ДНК в ядрах) методом проточной цитометрии и определения уровня плоидности для 30 видов семейства Chenopodiaceae в 50 популяциях из природных местообитаний России, Армении, Беларуси, Казахстана, Таджикистана и Южной Кореи. Впервые размер генома был определен у 12 видов, это A. patens, A. pedunculata, A. sibirica, A. verruci- 
fera, Axyris amaranthoides, Camphorosma songorica, Ceratocarpus arenarius, Chenopodium vachellii, Corispermum declinatum, Oxybasis gubanovii, Salsola collina, Spirobassia hirsuta. У образцов 13 видов (Atriplex patens, A. prostrata, Bassia prostrata, Chenopodium album, C. betaceum, C. frutescens, C. karoi, C. luteorubrum, C. novopokrovskianum, C. strictum s. l., C. vachellii, Krascheninnikowia ceratoides, и Oxybasis gubanovii) из 23 популяций уровень плоидности был определен также прямым подсчетом хромосом. Размер генома 11 видов был определен в двух и более популяциях. Показано, что различия в размере генома образцов в популяциях из различных участков ареала у диплоидов Atriplex sagittata, A. sibirica и у тетраплоидов Atriplex patens, Chenopodium album, C. betaceum, C. novopokrovskianum, C. strictum и Krascheninnikovia ceratoides не превышают 5 \%. Два цитотипа были выявлены у Bassia prostrata: диплоидный в республике Алтай и тетраплоидный в Новосибирской области. Выявлено наличие тетраплоидного цитотипа Chenopodium sosnovskyi на территории Армении. Показано, что размер генома может являться надежным критерием для определения уровня плоидности у родственных таксонов семейства Chenopodiaceae.

\section{Introduction}

Polyploidy is widespread among angiosperms and is an important factor of speciation (Otto, 2007; Soltis et al., 2009; Jiao et al., 2011). While developing molecular methods in taxonomy, classical studies in karyology are carried out on a much smaller scale in the world. Currently, interest in karyological research has increased, as interpreting molecular phylogenetic data are almost impossible without taking into account polyploidy in taxa evolution. Chromosome number and ploidy level are important characteristics, which help understanding the relationship between closely related species. Recent estimates show that $25-30 \%$ of flowering plants are polyploids (Hegarty, Hiscock, 2008; Wood et al., 2009; Scarpino et al., 2014; Barker et al., 2016). To determine ploidy level of plants by direct count in metaphase on squash preparations of root meristem is a labor-intensive method requiring the availability of samples collected in the fruiting stage. In addition, it is not always possible to germinate seeds and "catch" the desired metaphase stage in meristems suitable for counting chromosomes and determining the ploidy level. Therefore, karyological data are limited mostly by chromosome numbers obtained in few samples of individual species, that does not allow to estimate a true value of polyploidy in the taxa evolution.

The Chenopodiaceae family includes about 1400 species (Kühn et al., 1993) distributed mainly in the extratropical regions of the Northern Hemisphere and play an important role in steppe and desert landscapes, as well as in ruderal habitats. Information on chromosome numbers is currently available for about $38 \%$ of the family taxa, one third of which are polyploids (Rice et al., 2015). Multiple cytotypes are given for a number of species. Among them, for example, are the following: Arthrocnemum macrostachyum (Moric.) K. Koch $2 n=18$, 36; Atriplex patens (Litv.) Iljin
$2 n=18,36 ;$ A. prostrata Boucher ex DC. $2 n=$ 18, 36; Chenopodium album L. $2 n=18,36,54$; Halocnemum strobilaceum (Pall.) M. Bieb. $2 n=$ 18, 36; Kalidium caspicum (L.) U.-Sternb. $2 n=$ 18, 36; Bassia (= Kochia) prostrata (L.) A. J. Scott $2 n=18,36,54 ;$ Krascheninnikovia ceratoides $(\mathrm{L}$. Gueldenst. $2 n=18,36,54$; Sarcocornia fruticosa (L.) A. J. Scott $2 n=18,36,54,72 ;$ S. perennis (Mill.) A. J. Scott $2 n=18,36,72 ;$ Suaeda fruticosa Forssk. ex J. F. Gmel. $2 n=18,36,54,72 ; S$. vera Forssk. ex J. F. Gmel. $2 n=18,36,54$. Most of the above species are morphologically polymorphic and have extensive ranges. Quite possibly, the presence of multiple cytotypes indicates species taxonomic heterogeneity, which is evident for such a widespread species as Chenopodium album. The most of its various cytotypes are treated now as separate species (e. g. Mandák et al., 2016). In this regard, a detailed study of polyploidization in the family Chenopodiaceae, search for morphological and genetic differences between cytotypes, assessment of their taxonomic status are particularly relevant.

Nowadays, the investigations are being intensively developed to determine the ploidy level by flow cytometry based on measuring the genome size (DNA content in the nuclei of plants). The DNA content in the haploid chromosome set (1C) is a main characteristic of the genome, and varies significantly in vascular plants from $1 \mathrm{C}=0.06 \mathrm{pg}$ in Genlisea aurea A. St.-Hill. (Fleischmann et al., 2014) up to 152.20 pg in Paris japonica (Franch. et Sav.) Franch (Pellicer et al., 2010). The popularity of this method is associated with the high speed and simplicity of the material analysis compared with chromosomes count in metaphase plates on squash preparations. Since DNA content in nuclei (genome size) is fairly constant in most species, it can serve as a marker and can distinguish taxa of different ranks, as well as to detect hidden biodiversity or initial stages of speciation (Murray, 2005; Kron et al., 2007; Suda 
et al., 2007; Loureiro et al., 2010). This method is widely used in phylogeography, population biology, and ecology (Bennet, 1987; Stace, 2000; Doležel et al., 2007; Kron et al., 2007; Suda et al., 2007; Husband et al., 2013; Šmarda et al., 2019).

Taxonomy of Chenopodiaceae is based primarily on morphological characters, which are often variable depending on nutrition and moisture conditions. The presence of a large number of morphotypes in some species in nature and widespread polyploidy in the family makes it difficult to identify the real biodiversity. The detailed cytogeographic analysis by flow cytometry of individual species from different parts of their distribution is an important tool to study taxonomy and evolutionary relationships of taxa. However, the method of flow cytometry allows determining quickly and effectively only the total DNA content in the nuclei regardless of chromosome numbers. To determine the ploidy level by cytometry data (genome size), it is necessary to compare this results with data on chromosome numbers at least of the same or closely related species (Suda et al., 2006). Particular caution should be proceeded to interpret the genome size information while studying taxa with known multiple cytotypes.

A few data on the genome size of some Chenopodiaceae taxa are available in the works of Barow, Meister (2003); Walker et al. (2005); Koce et al. (2008), Ayres et al. (2009), Aouissat et al. (2009); Šmarda et al. (2019), Seidl et al. (2019), and in some others. The genome size of Chenopodium is studied more detailed (Kolano et al., 2015, 2019; Mandák et al., 2016, 2018; Vít et al., 2016). At that, present published data contain information on the genome size specified only for 112 taxa of the Chenopodiaceae family reflecting about $8 \%$ of the species.

Thereby, the aim of the present study is (1) to characterize ploidy level of 30 Chenopodiaceae taxa (50 populations) growing in East Europe and North Asia by genome size assessment and simultaneously by direct chromosome counting in 13 species, (2) to identify relationship between the ploidy level, the number of chromosomes and the genome size.

\section{Materials and methods}

Materials to study were collected in 50 populations from natural habitats of Russia, Armenia, Belarus, Kazakhstan, Tajikistan and South Korea (see the table in the appendix on the journal website). To determine the genome size, live leaves of plants, cultivated in the laboratory from seeds of herbarium specimens or collected directly in nature, were used. Vouchers are stored in the herbarium of the Central Siberian Botanical Garden - NS (acronym follows Thiers 2008+).

Seeds were germinated on sterile sand. Some seedlings of each sample were fixed for chromosome counting, the rest were transferred to plastic containers with standard soil for further growing. The chromosome number was determined by direct counting in the metaphase stage on root meristem of squash preparations. For prefixation treatment, the seedlings were kept for 2 hours at room temperature in $0.2 \%$ colchicine solution, fixed in acetic acid alcohol $(3: 1)$. The preparations were stained with acetogematoxilin according to Smirnov (1968), examined at Axioscope 40 microscope using the AxioVision 4.8 software and Axioscope A1 microscope with the Axiocam 506 color camera and ZEN2012 (blue edition) software.

The plant nuclear DNA content (2C) was determined by flow cytometry with staining of isolated nuclei with propidium iodide (PI). The analysis was performed using a CyFlow Space flow cytometer (Germany, Sysmex Partec) with a laser radiation source of $532 \mathrm{~nm}$. Leaf blades from the middle part of the shoot were taken for analysis. The nuclei of the standard and the sample were isolated and stained simultaneously in one test tube. A 0.5 $\times 0.5 \mathrm{~cm}$ piece of fresh leaf was crushed using a sharp blade in plastic Petri dishes together with an appropriate amount of internal standard in $500 \mu 1$ of Tris-MgCl2 chilled buffer (200 mm Tris, $4 \mathrm{~mm}$ $\mathrm{MgCl} 2 \cdot 6 \mathrm{H} 2 \mathrm{O}, 0.5 \%(\mathrm{v} / \mathrm{v})$ Triton X-100, $\mathrm{pH} 7.5)$ (Pfosser et al., 1995) adding propidium iodide $(50 \mathrm{mg} /$ $\mathrm{ml})$, RNA-Aza (50 $\mathrm{mg} / \mathrm{ml})$, and polyvinylpyrolidone (1\%). The samples were incubated at room temperature for $1 \mathrm{~min}$. After nuclei extraction, the samples were filtered through a disposable filter CellTrics Partec $30 \mu \mathrm{m}$ (Germany, Sysmex Partec) and added $1.5 \mathrm{ml}$ of staining solution once more. Staining was carried out at room temperature in a dark place for 15 minutes. The sample was then placed in a sample intake and analyzed using green laser with $532 \mathrm{~nm}$ wavelength under 30-50 events per minute. Fluorescence data obtained during detection of 10000-15000 events with an average value of coefficient of variation (CV) about $5 \%$. We analyzed 3 plants from a population repeating over 3 consecutive days to eliminate the device error (Doležel, Bartoš, 2005). Fresh plant leaves with known DNA content were used as internal standards to calculate the relative DNA content of the studied 
samples: Raphanus sativus L. 'Saxa' $(2 \mathrm{C}=1.11$ pg) (Doležel et al., 1992), Solanum lycopersicum Stupicke $(2 \mathrm{C}$ DNA content $=1.96 \mathrm{pg})$ (Doležel et al., 1992), Glycine max 'Polanka' (2C DNA content $=2.50 \mathrm{pg})($ Doležel et al., 1994), Pisum sativum L. 'Ctirad' ( $2 \mathrm{C}=9.09 \mathrm{pg}$ ) (Doležel et al., 1998). The seeds of these standards were obtained from the Center for Structural and Functional Plant Genomics of the Institute of Experimental Botany of the Academy of Sciences of the Czech Republic, Olomouc-Holice. Leaves of Chenopodium album $(2 \mathrm{C}=3.894 \mathrm{pg})$ proposed as an alternative standard by Vít et al. (2016) or Petroselinum crispum L. $(2 \mathrm{C}=4.5 \mathrm{pg})$ according to Skaptsov et al. (2016) were used as an internal standard for some samples. The analysis was carried out in 5 repetitions over 3 consecutive days to exclude the device error.

The relative content of nuclear DNA was calculated based on the linear relationship between the fluorescent signals from the colored nuclei of the studied samples and the internal standard according to the formula (Doležel et al., 2007):

$2 \mathrm{C}$ of sample $(\mathrm{pg})=2 \mathrm{C}$ of standard $(\mathrm{pg}) \times$ average peak fluorescence $G_{0} / G_{1}$ of sample / average peak fluorescence $\mathrm{G}_{0} / \mathrm{G}_{1}$ of standard.

The obtained results were processed using Statistica 8.0 (StatSoft Inc.) software and standard software of CyFlow ${ }^{\circledR}$ Space cytometer.

\section{Results and discussion}

The genome size (DNA content in nuclei) was determined in 30 species of the Chenopodiaceae family from 50 populations (see the table in the appendix on the journal website). The name of some taxa adopted in accordance with the latest systems based on the complex analysis data using molecular phylogenetic methods (Kadereit, Freitag, 2011; Fuentes-Bazan et al., 2012). Following S. L. Mosyakin (2017), for European and West Asian populations of the widespread species Chenopodium strictum s. 1 . we accept the name $C$. betaceum, not previously used in the taxonomic literature. From the other hand, we still treated here specimens from East Asian population of this taxon under the name C. strictum s. 1., as the taxonomy of eastern populations of this taxon need to be clarified.

For the first time the genome size was determined in 12 species: Atriplex patens, A. pedunculata, A. sibirica, A. verrucifera, Axyris amaranthoides, Camphorosma songorica, Ceratocarpus arenarius, Chenopodium vachellii, Corispermum declinatum, Oxybasis gubanovii, Salsola collina, and Spirobas- sia hirsuta. The minimum genome size $(2 \mathrm{C}=$ $0.77 \mathrm{pg}$ ) was found in Axyris amaranthoides, the maximum one $(2 \mathrm{C}=6.88 \mathrm{pg})$ in Chenopodium frutescens.

Along with flow cytometric analyses, in 23 samples of 12 species chromosome numbers were determined by direct counting in root tips meristems (Fig.). These species are Atriplex patens, A. prostrata, Bassia prostrata, Chenopodium album, C. betaceum, C. frutescens, C, karoi, C. novopokrovskianum, C. strictum, C. vachellii, Krascheninnikovia ceratoides, and Oxybasis gubanovii. Data on chromosome numbers of other species were taken from the database (Rice et al., 2015) available at: http://ccdb.tau.ac.il, or directly from literature. The exception is Camphorosma songorica, as there are no data on chromosome numbers of this species. This genus contains four species, two perennials (C. monspeliaca $\mathrm{L}$. and C. lessingii Litv.) and two annuals (C. annua Pall. and $C$. songorica Bunge). Three species, except for $C$. songorica, have information on chromosome numbers, all of them are diploids with $2 n=12$. The sufficiently large genome size of $C$. songorica $(2 \mathrm{C}=3.06 \mathrm{pg})$, which is not typical for other diploid representatives of the Chenopodiaceae, does not allow us to interpret accurately this data with respect to the ploidy level.

Eleven species were studied from two or more populations (see the table in the appendix on the journal website). Populations of diploid species Atriplex sagittata, A. sibirica and Chenopodium suecicum are located close to each other, and the studied samples differ slightly in the genome size. At the same time, the genome sizes of Atriplex prostrata in populations from the Primorye and Altai Territories differed by almost $10 \%$ (1.89 pg and $1.71 \mathrm{pg}$ respectively), that may be due to diverse habitat ecology in different botanical and geographical zones. Despite the fact, that genome size is constant within a species, a certain degree of intraspecific variation can be observed (Greilhuber, 1998). The genome size variations less than $5 \%$ were detected in populations of related tetraploid species from different areas of the range. Among them are: Atriplex patens studied from Belarus and Primorye Territory, Chenopodium betaceum from Tajikistan, and from Orenburg and Novosibirsk Regions; C. novopokrovskianum from Kazakhstan and Republic of Altai; C. strictum s. 1. from Primorye Territory and South Korea. For all studied specimens of these species, the tetraploid level was confirmed by direct chromosome counting. From the other 


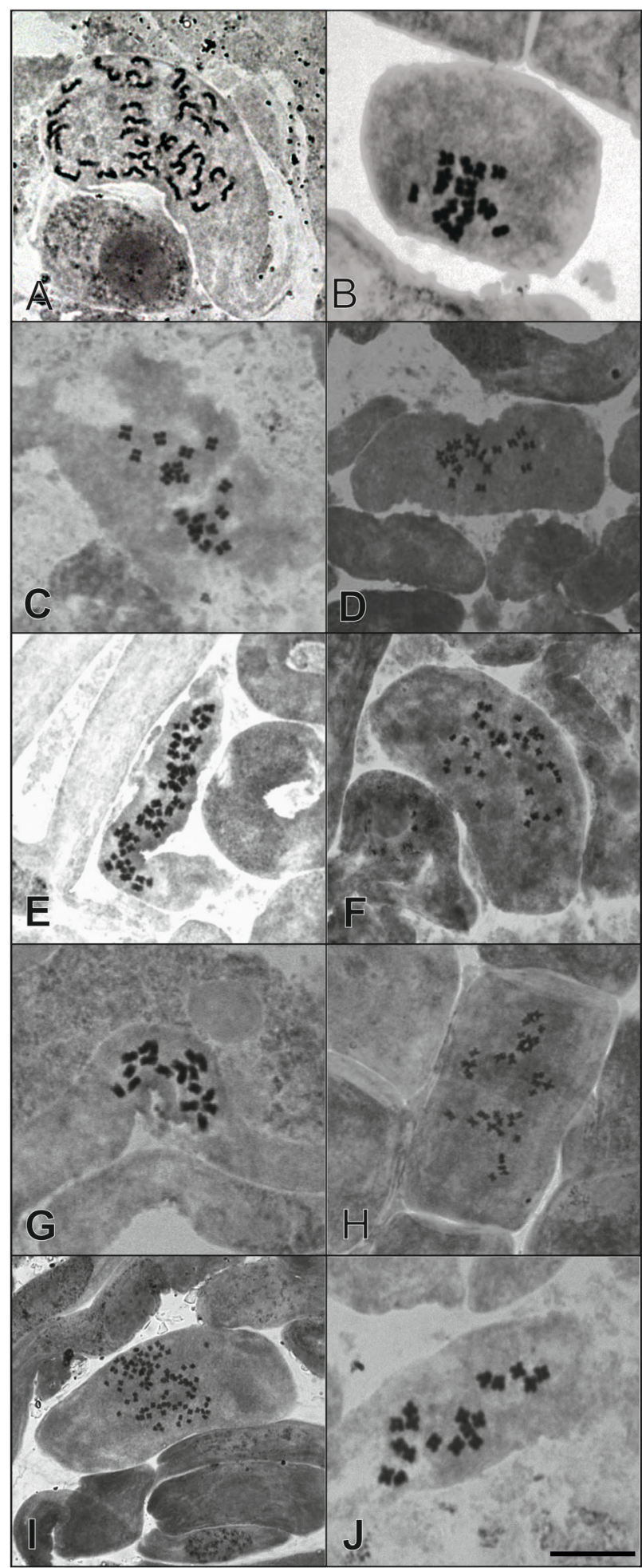

Fig. Mitiotic metaphase of some species of Chenopodiaceae: A - Atriplex patens $2 n=36$; B - Atriplex sibirica $2 n=18 ; \mathrm{C}-$ Atriplex prostrata $2 n=18 ; \mathrm{D}-$ Atriplex tatarica $2 n=18 ; \mathrm{E}-$ Chenopodium album $2 n=54$; $\mathrm{F}-$ Chenopodium strictum $2 n=36 ; \mathrm{G}-$ Chenopodium suecicum $2 n=18 ; \mathrm{H}-$ Chenopodium karoi $2 n=36$; $\mathrm{I}-$ Chenopodium frutescens $2 n=90 ; \mathrm{J}-$ Kochia scoparia $2 n=18$. Scale bars $=10 \mu \mathrm{m}$. hand, samples of Krascheninnikovia ceratoides studied from the highlands in Republic of Altai and from plain in Novosibirsk Region varied in the genome size $(2 \mathrm{C}=5.14 \mathrm{pg}$ and $4.79 \mathrm{pg}$ respectively). The tetraploid level of the Altai Republic's samples was confirmed by direct chromosome counting. Taking into account that the genome size difference of Novosibirsk and Altai samples is about $7 \%$, the observed difference may be due again to the environmental factors. The genome size intraspecific variation related to ecology is likely to be common and has been identified in Hordeum (Jakob et al., 2004), Picris hieracioides (Slovák et al., 2009), Festuca pallens (Šmarda, Bureš, 2010), Silene ciliata (García-Fernández et al., 2012), Cyanus (Olšavská et al., 2012), Filago (Andres-Sanchez et al., 2013) and in other taxa.

Another regularity was observed in Bassia prostrata studied in two populations from the Altai highlands and from Novosibirsk Region. The genome size in these populations differs twice, which indicates the presence of two separate cytotypes: diploid $(2 x)$ one in the Republic of Altai with $2 \mathrm{C}=2.21 \mathrm{pg}$, its ploidy level confirmed by direct chromosome counting, and tetraploid $(4 x)$ one in Novosibirsk Region, which genome size is $2 \mathrm{C}=4.55$ pg. Another example of two cytotypes occurrence in one species is Chenopodium sosnovskii described from Transcaucasia. The genome size of this species $(2 \mathrm{C}=2.22 \mathrm{pg})$ was determined in this study on the Armenian material, corresponds to the data obtained earlier on Iranian samples (Mandák et al., 2016), for which this authors proved the tetraploid level $(2 n=4 x=36)$ by direct chromosome counting. Additionally, Mandák et al. (2018) confirmed the allopolyploid origin of tetraploid cytotype of this species. At the same time, samples of C. sosnovskyi from Georgia, according to Gagnidze et al. (2006), are diploids with $2 n=2 x=18$. To establish the taxonomic relationship of these cytotypes, further cytogeographic studies of this polyploid complex in the Caucasus are needed. The presence of two distinct cytotypes in different range parts of a species requires more detailed investigation, as it may reflect their taxonomic isolation (Shneyer et al., 2018).

In general, the genome size values obtained in this study correspond to the published data. This applies primarily to the data of Chenopodium species whose genome size data were based on 
wide Eurasian materials (Mandák et al., 2016; Vít et al., 2016). Our results show that the genome size in the Chenopodiaceae family is a fairly reliable indicator to determine the ploidy level in related taxa within the same genus, and can be the basis for cytogeographic studies of polyploid complexes, which allow identifying quickly the ploidy levels of a large number of samples in a short time.

\section{Acknowledgements}

The investigation was carried out with support by a grant of the Russian Fund for Basic Research (19-04-00546-a) and scientific program AAAA-A17-117012610055-3 of the Central Siberian Botanical Garden SB RAS.

\section{REFERENCES / ЛИTEPATУPA}

Andrés-Sánchez S., Temsch E. M., Rico E., Martínez-Ortega M. M. 2013. Genome size in Filago L. (Asteraceae, Gnaphalieae) and related genera: phylogenetic, evolutionary and ecological implications. Plant Systematics and Evolution 299(2): 331-345 DOI: 10.1007/s00606-012-0724-3

Aouissat M., Belkhoja M., Hcini D., Correal E. 2009. Estimation of nuclear DNA content in Algerian populations of Atriplex halimus and Atriplex canescens by flow cytometry. Annales de Biologia 31: 15-18.

Ayres D., Ryan F. J., Grotkopp E., Bailey J., Gaskin J. 2009. Tumbleweed (Salsola, section Kali) species and speciation in California. Biological Invasions 11(5): 1175-1187. DOI: 10.1007/s10530-008-9380-5

Barker M. S., Arrigo N., Anthony E., Baniaga A. E., Li Z., Levin D. A. 2016. On the relative abundance of autopolyploids and allopolyploids. New Phytologist 210(2): 391-398. DOI: 10.1111/nph.13698

Barow M., Meister A. 2003. Endopolyploidy in seeds plants is differently correlated to systematics, organ, life and genome size. Plant cell and environment 26: 571-584.

Bennett M. D. 1987. Variation in genomic form in plants and its ecological implication. New Phytologist 106: 177-200. DOI: $10.1111 / j .1469-8137.1987 . t b 04689 . x$

Doležel J., Bartoš J. 2005. Plant DNA flow cytometry and estimation of nuclear genome size. Annals of Botany 95(1): 99-110. DOI: 10.1093/aob/mci005

Doležel J., Doleželová M., Novák F. J. 1994. Flow cytometric estimation of nuclear DNA amount in diploid bananas (Musa acuminata and M. balbisiana). Biologia Plantarum 36(3): 351-357. DOI:10.1007/BF02920930

Doležel J., Greilhuber J., Lucretti S., Meister A., Lysák M. A., Nardi L., Obermayer R. 1998. Plant genome size estimation by flow cytometry: Inter-laboratory comparison. Annals of Botany 82 Supp A: 17-26. DOI: 10.1006/ anbo.1998.0730

Doležel J., Greilhuber J., Suda J. 2007. Estimation of nuclear DNA content in plants using flow cytometry. Nature Protocols 2(9): 2233-2244. DOI: 10.1038/nprot.2007.310

Doležel J., Sgorbati S., Lucretti S. 1992. Comparison of three DNA fluorochromes for flow cytometric estimation of nuclear DNA content in plants. Physiologia Plantarum 85(4): 625-631. DOI: 10.1111/j.1399-3054.1992.tb04764.x.

Fleischmann A., Michael T. P., Rivadavia F., Sousa A., Wang W., Temsch E. M., Greilhuber J., Müller K. F., Heubl G. 2014. Evolution of genome size and chromosome number in the carnivorous plant genus Genlisea (Lentibulariaceae) with a new estimate of the minimum genome size in angiosperms. Annals of Botany 114(8): 1651-1663. DOI: $10.1093 / \mathrm{aob} / \mathrm{mcu} 189$

Fuentes-Bazan S., Uotila P., Borsch T. 2012. A novel phylogeny-based generic classification of Chenopodium sensu lato, and a tribal rearrangement of Chenopodioideae (Chenopodiaceae). Willdenowia 42(1): 5-24. DOI: 10.3372/wi.42.42101

Gagnidze R. I., Gviniashvili Ts. N., Djindjolia L. D. 2006. Chromosome numbers of some species of the Georgian flora. Bot. Zhurn. (Moscow \& St. Petersburg) 91(12): 1928-1929. [In Russian] (Гагнидзе Р. И., Гвиниашвили Ц. Н., Джинджслии Л. Д. Числа хромосом некоторых видов флоры Грузии // Бот. журн., 2006. Т. 91, № 12. C. 1928-1929).

García-Fernández A., Iriondo J. M., Vallés J., Orellana J., Escudero A. 2012. Ploidy level and genome size of locally adapted populations of Silene ciliata across an altitudinal gradient. Plant Systematics and Evolution 298(1): 139-146. DOI: 10.1007/s00606-011-0530-3.

Greilhuber J. 1998. Intraspecific variation in genome size in angiosperms: a critical reassessment. Annals of Botany 82: 27-35.

Hegarty M. J., Hiscock S. J. 2009. The complex nature of allopolyploid plant genomes. Heredity 103(2): 100101. DOI: $10.1038 /$ hdy.2009.61

Husband B. C., Baldwin S. J., Suda J. 2013. The incidence of polyploidy in natural plant populations: major patterns and evolutionary processes. In: Plant Genome Diversity. Vol. 2. Eds. I. J. Leitch, J. Greilhuber, J. Doležel, J. F. Wendel. New York: Springer. Pp. 255-276. DOI: 10.1007/978-3-7091-1160-4_16 
Jakob S. S., Meister A., Blattnert F. R. 2004. Considerable genome size variation of Hordeum species (Poaceae) is linked to phylogeny, life form, ecology, and speciation rates. Molecular Biology and Evolution 21(5): 860-869. DOI: 10.1093/molbev/msh092

Jiao Y., Wickett N. J., Ayyampalayam S., Chanderbali A. S., Landherr L., Ralph P. E., Tomsho L. P., Hu Y., Liang H., Soltis P. S., Soltis D. E., Clifton S. W., Schlarbaum S. E., Schuster S. C., Ma H., Leebens-Mack J., de Pamphilis $\boldsymbol{C}$. W. 2011. Ancestral polyploidy in seed plants and angiosperms. Nature 473(7345): 97-100. DOI: 10.1038/nature09916

Kadereit G., Freitag H. 2011. Molecular phylogeny of Camphorosmeae (Camphorosmoideae, Chenopodiaceae): Implications for biogeography, evolution of $\mathrm{C}_{4}$-photosynthesis and taxonomy. Taxon 60(1): 51-78. DOI: 10.1002/ tax.601006

Koce J. D., Škondrić S., Bačič T., Dermastia M. 2008. Amounts of nuclear DNA in marine halophytes. Aquatic Botany 89(4): 385-389. DOI: 10.1016/j.aquabot.2008.04.009

Kolano B., McCann J., Oskędra M., Chrapek M., Rojek M., Nobis A., Weiss-Schneeweiss H. 2019. Parental origin and genome evolution of several Eurasian hexaploid species of Chenopodium (Chenopodiaceae). Phytotaxa 392(3): 163-185. DOI: 10.11646/phytotaxa.392.3.1

Kolano B., Siwinska D., McCann J., Weiss-Schneeweiss H. 2015. The evolution of genome size and rDNA in diploid species of Chenopodium s. 1. (Amaranthaceae). Botanical Journal of the Linnean Society 179: 218-235. DOI: 10.1111/boj.12321

Kron P., Suda J., Husband B. C. 2007. Applications of flow cytometry to evolutionary and population biology. Annual Review of Ecology, Evolution, and Systematics 38: 847-876. DOI: 10.1146/annurev.ecolsys.38.091206.095504

Kühn U., Bittrich V., Carolin R., Freitag H., Hedge I. C., Uotila P., Wilson P. G. 1993. Chenopodiaceae. In: The families and genera of vascular plants. Vol. 2. Eds. K. Kubitzki, J. G. Rohwer, V. Bittrich. Berlin, Heidelberg: Springer. Pp. 253-281. DOI: 10.1007/978-3-662-02899-5_26

Loureiro J., Trávníček P., Rauchová J., Urfus T., Vít P., Štech M., Castro S., Suda J. 2010. The use of flow cytometry in the biosystematics, ecology and population biology of homoploid plants. Preslia 82(1): 3-21.

Mandák B., Krak K., Vít P., Lomonosova M. N., Belyaev A., Habibi F., Wang L., Douda J., Štorchová H. 2018. Hybridization and polyploidization within Chenopodium album aggregate analyzed by means of cytological and molecular markers. Molecular Phylogenetics and Evolution 129: 189-201. DOI: 10.1016/j.ympev.2018.08.016

Mandák B., Krak K., Vít P., Pavlíková Z., Lomonosova M. N., Habibi F., Lei W., Jellen E. N., Douda J. 2016. How genome size variation is linked with evolution within Chenopodium sensu lato. Perspectives in Plant Ecology, Evolution and Systematics 23: 18-32. DOI: 10.1016/j.ppees.2016.09.004

Mosyakin S. L. 2017. Notes on taxonomy and nomenclature of Chenopodium acerifolium and C. betaceum (C. strictum auct.) (Chenopodiaceae). Phytotaxa 324(2): 139-154. DOI: 10.11646/phytotaxa.324.2.3

Murray B. G. 2005. When does intraspecific C-value variation become taxonomically significant? Annals of Botany 95(1): 119-125. DOI: 10.1093/aob/mci007

Olšavská K., Perný M., Španiel S., Šingliarová B. 2012. Nuclear DNA content variation among perennial taxa of the genus Cyanus (Asteraceae) in Central Europe and adjacent areas. Plant Systematics and Evolution 298(8): 1463-1482. DOI: $10.1007 / \mathrm{s} 00606-12-0650-4$

Otto S. P. 2007. The evolutionary consequences of polyploidy. Cell 131:452-462. DOI: 10.1016/j.cell.2007.10.022

Pellicer J., Fay M. F., Leitch I. J. 2010. The largest eukaryotic genome of them all? Botanical Journal of the Linnean Society 164(1): 10-15. DOI: 10.1111/j.1095-8339.2010.01072.x.

Pfosser M., Amon A., Lelley T., Heberle-Bors E. 1995. Evaluation of sensitivity of flow cytometry in detecting aneuploidy in wheat using disomic and ditelosomic wheat-rye addition lines. Cytometry 21(4): 387-393. DOI: 10.1002/cyto.990210412.

Rice A., Glick L., Abadi S., Einhorn M., Kopelman N. M., Salman-Minkov A., Mayzel J., Chay O., Mayrose I. 2015. The Chromosome Counts Database (CCDB) - a community resource of plant chromosome numbers. New Phytologist 206(1): 19-26. URL: http://ccdb.tau.ac.il (Accessed 30 September 2019).

Scarpino S. V., Levin D. A., Meyers L. A. 2014. Polyploid formation shapes flowering plant diversity. The American Naturalist 184(4): 456-465. URL: http://www.jstor.org/stable/10.1086/677752.

Seidl A., Pérez-Collazos E., Tremetsberger K., Carine M., Catalán P., Bernharg K-G. 2019. Phylogeny and biogeography of the Pleistocene Holarctic steppe and semi-desert goosefoot plant Krascheninnikovia ceratoides. Flora (accepted paper DOI: 10.1016/j.flora.2019.151504).

Shneyer V. S., Punina E. O., Rodionov A. V. 2018. Intraspecific variation of ploidy in angiosperms and its taxonomical treatment. Bot. Zhurn. (Moscow \& St. Petersburg) 103(5): 555-585. [In Russian] (Шнеер В. С., Пунина $\boldsymbol{E}$. $\boldsymbol{O} .$, Родионов $\boldsymbol{A}$. B. Внутривидовые различия в плоидности и их таксономическая интерпретация // Бот. журн., 2018. Т. 103, № 5. С. 555-585).

Skaptsov M. V., Smirnov S. V., Kutsev M. G., Shmakov A. I. 2016. Problems of standardization in plant flow cytometry. Turczaninowia 19, 3: 120-122. [In Russian] (Скапцов М. В., Смирнов С. В., Куцев М. Г., Шмаков А. И. 
Проблемы стандартизации в проточной цитометрии растений // Turczaninowia, 2016. Т. 19, вып. 3. С. 120-122). DOI: 10.14258/turczaninowia.19.3.9

Slovák M., Vít P., Urfus T., Suda J. 2009. Complex pattern of genome size variation in a polymorphic member of the Asteraceae. Journal of Biogeography 36(2): 372-384 DOI: 10.1111/j.1365-2699.2008.02005.x.

Šmarda P., Bureš P. 2010. Understanding in intraspecific variation in genome siza. Preslia 82(1): 41-61.

Šmarda P., Knápek O., Březinová A., Horová L., Grulich V., Danihelka J., Veselý P., Šmerda J., Rotreklová O., Bureš P. 2019. Genome sizes and genomic guanine+cytosine (GC) contents of the Czech vascular flora with new estimates for 1700 species. Preslia 91(2): 117-142. DOI: 10.23855/preslia.2019.117.

Smirnov Yu. A. 1968. Accelerated method for studying somatic chromosomes in fruit trees. Tsitologiya [Cytology] 10(12): 1132-1134. [In Russian] (Смирнов Ю. А. Ускоренный метод исследования соматических хромосом плодовых // Цитология, 1968. Т. 10, № 12. С. 1132-1134).

Soltis D. E., Albert V. A., Leebens-Mack J., Bell C. D., Paterson A. H., Zheng C., Sankoff D., dePamphilis C. W., Wall P. K., Soltis P. S. 2009. Polyploidy and angiosperm diversification. American Journal of Botany 96(1): 336-348. DOI: 10.3732 ajb.0800079

Stace C. A. 2000. Cytology and cytogenetics as a fundamental taxonomic resource for the $20^{\text {th }}$ and $21^{\text {st }}$ centuries. Taxon 49(3): 451-477. DOI: 10.2307/1224344.

Suda J., Krahulcová A., Trávnícek P., Krahulec F. 2006. Ploidy level versus DNA ploidy level: an appeal for consistent terminology. Taxon 55(2): 447-450. DOI: 10.2307/25065591.

Suda J., Kron P., Brian C. Husband B. C., Trávnièek P. 2007. Flow cytometry and ploidy: applications in plant systematics, ecology and evolutionary biology. In: Flow cytometry with plant cells: analysis of genes, chromosomes and genomes. Eds. J. Doležel, J. Greilhuber, J. Suda. Weinheim: Willey-vch. Pp. 103-130.

Thiers B. 2008+ [continuously updated]. Index Herbariorum: A global directory of public herbaria and associated staff. New York Botanical Garden's Virtual Herbarium. URL: http://sweetgum.nybg.org/science/ih (Accessed 01 October 2019).

Vít P., Krak K., Trávníček P., Douda J., Lomonosova M. N., Mandák B. 2016. Genome size stability across Eurasian Chenopodium species (Amaranthaceae). Botanical Journal of the Linnean Society. 182(3): 637-649. DOI: 10.1111/boj.12474

Walker D. J., Moñino I., González E., Frayssinet N., Correal E. 2005. Determination of ploidy and nuclear DNA content in populations of Atriplex halimus (Chenopodiaceae). Botanical Journal of the Linnean Society 147(4): 441-448. DOI: 10.1111/j.1095-8339.2004.00379.x

Wood T. E., Takebayashi N., Barker M. S., Mayrose I., Greenspoon P. B., Rieseberg L. H. 2009. The frequency of polyploid speciation in vascular plants. Proceedings of the National Academy of Sciences 106(33): 13875-13879. DOI: $10.1073 /$ pnas.0811575106 